\title{
Study on Antibacterial Activity of Anthocyanins from Blueberry Wine Pomace
}

\author{
Chen $\mathrm{Liu}^{1}$, Anjun Liư ${ }^{1}$, Yanhong $\mathrm{Ma}^{2}$, Kaihong Huang ${ }^{2}$, Yahui Li ${ }^{2}$, Hongzhi \\ Zhang $^{2}$
}

${ }^{1}$ The School of Food Engineering and Biological Technology, Tianjin University of Science and Technology

${ }^{2}$ Institute of Agro-product processing, Jiangsu Academy of Agricultural Sciences

Keywords: Blueberry wine pomace, anthocyanins, antibacterial activity

\begin{abstract}
This paper studied the antibacterial activity of the anthocyanins from blueberry wine pomace. The blueberry wine pomace, which is by product in blueberry wine process, is rich in anthocyanins, and the anthocyanins extract from blueberry wine pomace, then the extraction was purified and components of purification were analyzed by HPLC. The common food contaminating bacteria such as S.aureus, E.coli and Salmonella were used as tested microorganisms. The diameter of inhibition zone and the value of the minimum inhibitory concentration (MIC) was used as the activity monitoring parameter. The main results are as follows: after analysed by high efficiency liquid chromatography, there are three kinds of anthocyanins in purified anthocyanins, and the Cyanidin-3-glucoside was confirmed. The sum of relative peak area for three kinds of anthocyanins is $62.81 \%$, and the anthocyanins displayed significant inhibition to S.aureus, E.coli and Salmonella, and assessment of minimum inhibitory concentration showed that anthocyanins of $5 \mathrm{mg} / \mathrm{mL}, 10$ $\mathrm{mg} / \mathrm{mL}$, and $20 \mathrm{mg} / \mathrm{mL}$ were the MIC value respectively.
\end{abstract}

\section{Introduction}

Anthocyanins (ACY), as a group of natural pigments, are abundant in blueberry. Previous reports showed that the bioactivity of anthocyanins is related to their strong antioxidant activity, and the health benefits of anthocyanins, such as antineoplastic, anti-inflammatory, vasotonic, vasoprotective, and hepatic protective effects are searched. As the antibacterial substances are used, there are many advantages of the anthocyanins, such as will do not generatedrug resistance, will not cause environmental pollution, no residue and so on. The studies of antibacterial activity are relatively scarce, and Cheng and Yue researched the effected of anthocyanins which were from Cortes and purple sweet potato on microorganismrespectively.

Blueberry wine pomace, by-product of blueberry wine, contains anthocyanins richly, which can be the material for anthocyanins extraction. Nowadays discharge of it not only causes pollution, also waste of resources. In the present study, the ultrasonic assistant extraction was used to extract the pigment, and the extract was purified by microporous resin AB-8, then thehigh performance liquid chromatography was used to analyze the components of purification. The S.aureus, E.coli and Salmonellawere designated as the tested bacteria, and we observed the inhibition ability of ACY by the diameters with filter paper and the minimum inhibitory concentration.

\section{Experimental}

\subsection{Material preparation}

Blueberry wine pomace were dried at $50^{\circ} \mathrm{C}$ in dark, shattered thoroughly, and then stored in vacuum pack in dark.

\subsection{Extraction and purification of anthocyanins}

We achieved the optimal methods after experiments. The acidified mixtures of ethanol with water $(\mathrm{v} / \mathrm{v}=7 / 3, \mathrm{pH}=3)$ were used for extraction. Powders were soaked in media for 10 min with the solid-liquid ratio of $1: 33(\mathrm{~g} / \mathrm{mL})$ in room temperature. After ultrasonic-assisted extraction (500 
$\mathrm{W}$ ) for $50 \mathrm{~min}$, the extraction continued for $1 \mathrm{~h}$ at $65^{\circ} \mathrm{C}$ twice. The supernatants were centrifuged at $4500 \mathrm{r} / \mathrm{min}$ for $20 \mathrm{~min}$. The activated microporous resin AB-8 was used to purify the extract, and the speed of sample loading was $1 \mathrm{ml} / \mathrm{min}$. After washed by the distilled water, mixtures of ethanol with water $(\mathrm{v} / \mathrm{v}=7 / 3)$ were used for desorption. The ethanol was removed from purified anthocyanin extract by rotary evaporation, and the extract was frozen dried for $24 \mathrm{~h}$. Extraction, purification, and storage processes were all in dark.

\subsection{Components of ACY assay}

The high performance liquid chromatography was used for analyzing the components of ACY from blueberry wine pomace. The Cyanidin-3-glucoside standard reference substance and the ACY from blueberry wine pomace were dissolved in methanol which with hydrochloric acid $(\mathrm{v} / \mathrm{v}=$ 1000/1), and stored in dark. The HPLC analysis was performed on a Waters HPLC system ( Waters, USA) with a Waters C-18 chromatographic column (3.5mm, $4.6 \mathrm{~mm} \times 150 \mathrm{~mm}$ ) (Waters, USA). The mobile phase was composed of acetonitrile (A) and $2 \%$ aqueous Methane acid (B). The gradient was as follows: $0-8 \mathrm{~min}, 0-5 \%($ solvent $\mathrm{A}$ ); $8.01-15 \mathrm{~min}, 5-50 \%$ (solvent $\mathrm{A}$ ); $15.01-17 \mathrm{~min}, 50-5 \%$ (solvent A); and 17.01-20 min, 5\% (solvent A). The temperature of the column was maintained at $35^{\circ} \mathrm{C}$, and the effluent was monitored at $535 \mathrm{~nm}$, the flow rate of mobile phase is $0.8 \mathrm{~mL} / \mathrm{min}$, the sample volume is $15 \mu \mathrm{L}$.

\subsection{Activation of bacteria}

The S.aureus, E.coli and Salmonellawere cultured in sterile liquid beef-protein medium at $37^{\circ} \mathrm{C}$ for $24 \mathrm{~h}$ in concussion incubatorrespectively. Then remove a certain amount ofliquid culture in sterile liquid beef-protein mediumrespectively, and bacteria were cultured for $24 \mathrm{~h}$.

\subsection{Diameter of inhibition zone assay}

The sterile filter paper (6mm in diameter) was soaked in various normal saline solution with or without anthocyanins $(0 \mathrm{mg} / \mathrm{mL}, 5 \mathrm{mg} / \mathrm{mL}, 10 \mathrm{mg} / \mathrm{mL}, 15 \mathrm{mg} / \mathrm{mL}, 20 \mathrm{mg} / \mathrm{mL}, 30 \mathrm{mg} / \mathrm{mL})$ for $2 \mathrm{~h}$ at $4^{\circ} \mathrm{C}$. Then three kinds of liquid culture were droped in sterile petri dishes with $15 \mathrm{ml}$ beef-protein agar medium, and were coated uniformly. The filter paper with various solition was put in the each petri dish, and bacteria were cultured inverted at $37^{\circ} \mathrm{C}$ for $24 \mathrm{~h}$ after $10 \mathrm{~min}$. Then we observed the inhibition zone, and measured the diameter in cross methed byvernier calipers.

\subsection{The minimum inhibitory concentrationassay}

Three kinds of liquid culture were added to liquid culture respectively, and poured various beefprotein agar medium with anthocyanins $(0.313 \mathrm{mg} / \mathrm{mL}, 0.625 \mathrm{mg} / \mathrm{mL}, 1.25 \mathrm{mg} / \mathrm{mL}, 2.5 \mathrm{mg} / \mathrm{mL}$, $5 \mathrm{mg} / \mathrm{mL}, 10 \mathrm{mg} / \mathrm{mL}, 20 \mathrm{mg} / \mathrm{mL}$ ) at $50{ }^{\circ} \mathrm{C}$ and mixed completely. After the medium solidified, bacteria were cultured inverted at $37^{\circ} \mathrm{C}$ for $24 \mathrm{~h}$. Then we observed if there are visible colonies.

\section{Results}

\subsection{The componentof ACY}

As the Fig. 1(a) showed, the retention time of cyaniding - 3- glucoside standard is 12.847s; and there are 3 main peaks in Fig. 1(b), and compared with the standard, the retention time of tenth peak is identical nearly, hence, we can determine the ACY extract contains centaur - 3- glucoside. Reference the previous studies, the eighth peak and the ninth peak are anthocyanins, and as the table. 1 showed, the total relative peak area of eighth, ninth, tenth peaks is $62.81 \%$.

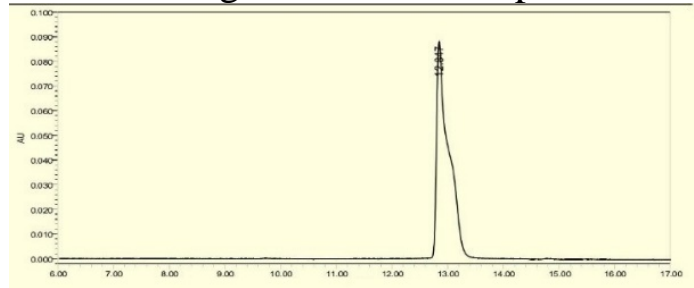

(a) 


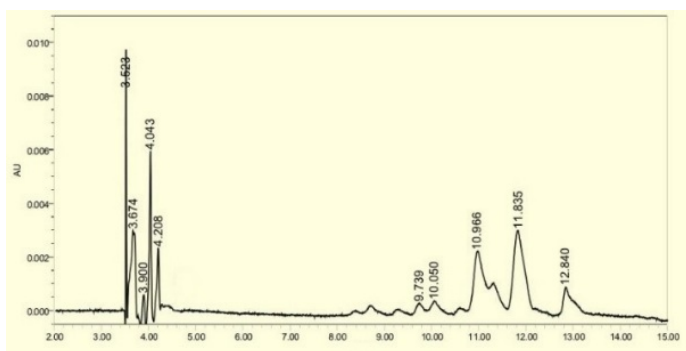

(b)

Figure 1. The component of ACY were analysis by HPLC analysis.

: HPLC spectrum of Cyanidin-3-glucoside, (b): HPLC spectrum of anthocyanins from blueberry wine pomace.

Table 1.Results of HPLC analysis.

\begin{tabular}{lllll}
$\begin{array}{l}\text { Number } \\
\text { Peaks }\end{array}$ & of & $\begin{array}{l}\text { Retention } \\
(\mathrm{s})\end{array}$ & $\begin{array}{l}\text { Time } \\
\text { Relative }\end{array}$ & $\begin{array}{l}\text { Peak } \\
(\%)\end{array}$ \\
\hline 1 & 3.523 & 6.03 & & \\
2 & 3.674 & 12.58 & & \\
3 & 3.900 & 2.13 & & \\
4 & 4.043 & 9.15 & & \\
5 & 4.208 & 3.86 & & \\
6 & 9.739 & 1.59 & & \\
7 & 10.050 & 1.85 & \\
8 & 10.966 & 26.11 & \\
9 & 11.835 & 28.79 & \\
10 & 12.840 & 7.91 & \\
\hline
\end{tabular}

\subsection{Diameter of inhibition zone analysis of anthocyanins}

The antibacterial activity of anthocyanins from blueberry wine pomace can be judged by observed the diameter of inhibition zone. As the Fig. 2 showed, the anthocyanins can inhibit the growth of theS.aureus, E.coli and Salmonella, and the inhibition zone was observed. Analyzed the data in table. 1, the anti-proliferation of theS.aureus, E.coli and Salmonella with anthocyanins was found in a concentration-dependent manner, and the diameters of inhibition zone were increased with the increasing concentrations of anthocyanins, and theinhibitory activity of the S.aureus is most obvious

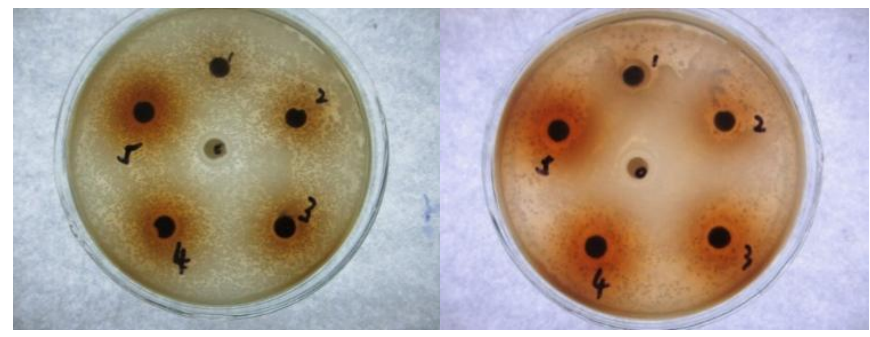

(a)(b)

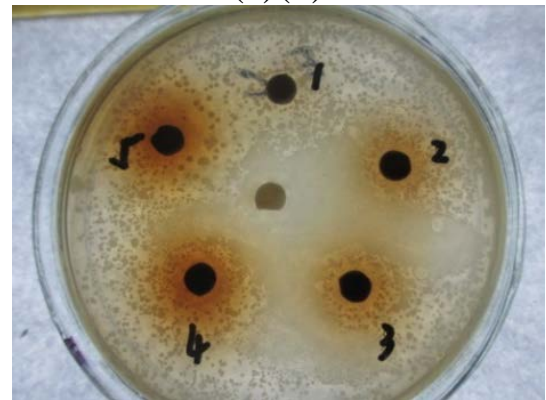

(c)

Figure 2. The effect of anthocyanins from blueberry wine pomace inhibit test bacteria.

: Salmonella; (b): S.aureus; (c)E.coli. No. 0 is control group, No. 1- 5 are tested groups which are 
with anthocyanins solution (5 mg/mL, $10 \mathrm{mg} / \mathrm{mL}, 15 \mathrm{mg} / \mathrm{mL}, 20 \mathrm{mg} / \mathrm{mL}, 30 \mathrm{mg} / \mathrm{mL}$ )

Table 2.The inhibitory effect of tested bacteria on anthocyanins from blueberry wine pomace

\begin{tabular}{|c|c|c|c|}
\hline \multirow{2}{*}{$\begin{array}{l}\text { The } \\
\text { concentration } \\
\text { of anthocyanins } \\
\text { solution } \\
\text { (mg/mL) }\end{array}$} & \multicolumn{3}{|c|}{ The diameter of inhibition zone $(\mathrm{mm})$} \\
\hline & Salmonella & S.aureus & E.coli \\
\hline $\begin{array}{l}0 \\
5\end{array}$ & $\begin{array}{l}6.42 \pm 0.141 \\
7.36 \pm 0.48\end{array}$ & $\begin{array}{l}6.18 \pm 0.141 \\
6.26 \pm 0.141\end{array}$ & $\begin{array}{l}6.31 \pm 0.212 \\
6.68 \pm 0.35+\end{array}$ \\
\hline 10 & $7.63 \pm 0.665$ & $7.36 \pm 0.65 \#$ & $7.79 \pm 0.184+$ \\
\hline 15 & $7.92 \pm 0.537 *$ & $8.17 \pm 0.806 \# \#$ & $8.19 \pm 0.156++$ \\
\hline 20 & $8.15 \pm 0.071^{* *}$ & $8.93 \pm 0.55 \#$ & $8.39 \pm 0.665$ \\
\hline 30 & $8.32 \pm 0.72 * *$ & $9.17 \pm 0.184 \# \#$ & $8.62 \pm 0.28++$ \\
\hline
\end{tabular}

and $* *$ indicated $\mathrm{p}<0.05$ and $\mathrm{p}<0.01$ respectively compared with the control group of Salmonella; \# and \#\# indicated $\mathrm{p}<0.05$ and $\mathrm{p}<0.01$ respectivelycompared with the control group ofS.aureus; + and ++ indicated $\mathrm{p}<0.05$ and $\mathrm{p}<0.01$ respectivelycompared with the control group of E.coli.

3.2 Diameter of inhibition zone analysis of anthocyanins

As the Table. 3 showed, when the concentration of anthocyanins was $5 \mathrm{mg} / \mathrm{mL}$, there were not visibleS.aureuscolonies in medium; and the MIC of E.coliandSalmonellaare $10 \mathrm{mg} / \mathrm{mL}$ and 20 $\mathrm{mg} / \mathrm{mL}$.

Table. 3: The minimum inhibitory concentration of anthocyanins from blueberry wine pomace for

\begin{tabular}{|c|c|c|c|c|c|c|c|}
\hline \multirow[b]{2}{*}{$\begin{array}{l}\text { Tested } \\
\text { Bactria }\end{array}$} & \multicolumn{6}{|c|}{$\begin{array}{l}\text { The concentration } \\
\text { anthocyaninssolution(mg/mL) }\end{array}$} & of \\
\hline & $\begin{array}{l}0.31 \\
3\end{array}$ & $\begin{array}{l}0.62 \\
5\end{array}$ & 1.25 & 2.5 & 5 & 10 & 20 \\
\hline Salmonella & +++ & +++ & +++ & +++ & ++ & + & - \\
\hline S.aureus & +++ & +++ & ++ & + & - & - & - \\
\hline E.coli & +++ & +++ & ++ & ++ & + & - & - \\
\hline
\end{tabular}

-indicated no visible colonies; +indicated the number of colonies isless than 30 ; ++ indicated the number of colonies is 30-300;+++ indicated the colonies cannot be counted.

\section{Conclusions}

The present study was focused on the antibacterial activity of anthocyanins from blueberry wine pomace.After analysed by high efficiency liquid chromatography, there are three kinds of anthocyanins in purified anthocyanins, and the Cyanidin-3-glucoside was confirmed. The sum of relative peak area for three kinds of anthocyanins is 62.81\%; and anthocyanins displayed significant inhibition to S.aureus, E.coli and Salmonella, and assessment of minimum inhibitory concentration showed that anthocyanins of $5 \mathrm{mg} / \mathrm{mL}, 10 \mathrm{mg} / \mathrm{mL}$, and $20 \mathrm{mg} / \mathrm{mL}$ were the MIC value respectively.

\section{Acknowledgement}

The authors thank the Institute of Agro-product processing of Jiangsu Academy of Agricultural Sciences and this work was supported by the Jiangsu Province National Natural Science Foundation of China (No. BK2012786). 


\section{References}

Degenhardt, H. Knapp, P. Winterhalter, 2000. Separation and purification of anthocyanins by highspeed countercurrent chromatography and screening for antioxidant ctivity. Journal of agricultural and food chemistry, 48(2), pp.338- 343.

E. Cacace, G. Mazza,2003.Mass transfer process during extraction of phenolic compounds from milled berries. Journal of Food Engineering, 59(4), pp.379-389.

Eunjin Shin, Chul Lee, Sang Hyun Sung, Young Choong Kim, Bang Yeon Hwang, Mi Kyeong Lee, 2011. Antifibrotic activity of coumarins from Cnidium monnieri fruits in HSC-T6 hepatic stellate cells. Journal of Natural Medicines 65, pp. 370-374.

G. Spagna, R. N. Barbagallo, A. Todaro, M.J. Durante, P.G. Pifferi, 2003.A method for anthocyanin extraction from fresh grape skin. Journal of Food Science, 15 (3), pp. 337-346.

J. H. Lee, M. G. Choung,2011.Identification and characterisation of anthocyanins in the antioxidant activity-containing fraction of Liriope platyphylla fruits, Food Chemistry, 127, pp. 1686-1693.

J. Vans, S. Millan, M. P Marti, E. Borras, L. Arola, 2009. Advanced separation methods of food anthocyanins, is of lavones and flavanols, Journal of Chromatography A, 1216, pp.7143-7172.

J. E. Cacace, G. Mazza,2002.Extraction of anthocyanins and other phenolics from black currants with sulfured water. Journal of Agricultural and Food Chemistry, 50, pp. 5939-5946.

Li Xiuxia, Han Lujia, Chen Longiian,2008. In vitro antioxidant activity of protein hydrolysates prepared from corn gluten meal. Journal of the Science of Food and Agriculture, 88(9), pp.16601666. 